\title{
SOSIS IKAN
}

\section{Ari Asnani}




\section{SOSIS IKAN}

\section{Ari Asnani}

Penanggung Jawab :

Prof. Dr. Ir. Suwarto, MS

\section{Ketua Umum :}

Karseno, SP., MP., Ph.D

\section{Wakil Ketua :}

Prof. Dr. Ning Iriyanti, MS

\section{Sekretaris :}

Drs. Sudiro, MM

\section{Tim Editor Isi :}

1. Dr. Tyas Retno Wulan, S.Sos., M.Si

2. Ir. Agus Suyanto, SU.D.Tech.Sc

3. Ir. Supartoto, M.Agr

4. Ir. Suparwi,MP

5. Karseno, SP., MP.,Ph.D

6. SH. Suseno, SU

7. Sri Hartini, SH., MA

\section{Tim Editor Penulisan :}

1. Drs. Subandi, M.Pd

2. Dra. Dyah Wijayanti, M.Pd

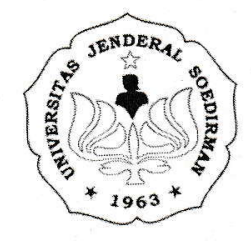

Lembaga Penelitian dan Pengabdian Kepada Masyarakat Universitas Jenderal Soedirman

Universitas Jenderarangwangkal, Purwokerto 53122

Telp./ Fax : (0281) 625739

Email : Ippm_unsoed@yahoo.co.id 


\section{KATA PENGANTAR}

Puji syukur kami panjatkan kepada Allah swt. atas rahmat dan karunia-Nya sehingga buku Teknologi Tepat Guna "Sosis Ikan" dapat diselesaikan. Penulisan buku ini bertujuan untuk memberikan informasi kepada masyarakat mengenai teknologi tepat guna untuk mengolah ikan menjadi sosis dan sosis ikan ekonomis. Buku TTG ini mengupas seluk beluk sosis ikan, bahan baku dan alat-alat produksi, cara pembuatan sosis ikan, pengemasan dan labeling, evaluasi gizi, serta analisis usaha sosis ikan.

Buku ini diharapkan dapat digunakan sebagai referensi produksi sosis ikan. Lebih jauh lagi, buku ini juga dapat menjadi acuan dalam kegiatan peningkatan pendapatan keluarga melalui wirausaha produksi sosis ikan. Saran dan kritik yang membangun akan sangat diperlukan agar buku teknologi tepat guna ini dapat lebih baik lagi pada masa yang akan datang.

Oktober 2016

Penyusun 


\section{DAFTAR ISI}

KATA PENGANTAR

Halaman

iii

DAFTAR ISI

DAFTAR GAMBAR

BAB 1. GEMAR MAKAN IKAN

1.1 Potensi Gizi Ikan

1.2 Teknologi Pengolahan Ikan

1.3 Sosis Ikan

BAB 2. BAHAN BAKU DAN ALAT PRODUKSI

2.1 Bahan Utama

2.2 Bahan Pendukung

2.3 Alat Produksi

BAB 3. PEMBUATAN SOSIS IKAN

3.1 Teknik Dasar Pembuatan Sosis ............................................. 19

3.2 Resep Dasar Sosis Ikan ............................................. 24

3.3 Sosis Ikan Ekonomis ...................................................... 28

3.4 Pengemasan dan Pelabelan $\ldots$

BAB 4. EVALUASI MUTU GIZI

4.2 Analisis Proksimat

4.3 Analisis Mikrobiologi Metode TPC ....................................... 40

4.4 Analisis Sensori ..................................................... 40

BAB 5. ANALISIS EKONOMI

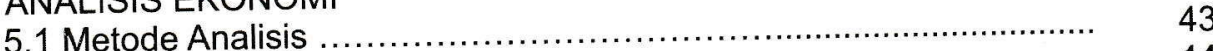

5.2 Metode Perhitungan ................................................... 44

DAFTAR PUSTAKA 


\section{DAFTAR GAMBAR}

1. Pengolahan ikan dengan menerapkan prinsip zero waste

Halaman

2. Contoh diversifikasi vertikal ikan patin

3

3. Ragam casing (a) casing kolagen, (b) casing selulosa, dan (c)

casing plastik polyamide transparan dan rich brown

4. Berbagai jenis alat penggiling daging: (a) alat manual, (b) food processor, (c) blender industri

5. (a) Contoh mesin sosis stuffer, dan (b) berbagai ukuran cetakan sosis

6. Ragam timbangan, (a) manual, dan (b) digital

7. Pengemas vacuum sealer

8. Rumput laut Eucheuma cottonii

9. Contoh label produk sosis ikan

10. Pengukuran tekstur sosis (a) Probe pisau mengukur daya iris,

11. Grafik pengukuran daya iris dan kekenyalan dengan Texture Analyzer TA-XT2i 


\section{BAB I \\ GEMAR MAKAN IKAN}

\subsection{Potensi Gizi Ikan}

Ikan merupakan sumber protein hewani dengan kandungan protein $17-24 \%$ dari beratnya dan memiliki daya cerna yang sangat tinggi (90\%) sehingga ikan merupakan sumber zat gizi yang penting. Protein daging dibagi menjadi tiga jenis, yaitu protein sarkoplasma, protein miofibrillar, dan protein stroma (Xiong, 2000). Protein sarkoplasma mengandung protein yang dapat larut dalam air (miogen) serta enzimenzim termasuk enzim proteolitik. Protein miofibrillar adalah protein yang membentuk benang-benang daging ikan (miofibril) dan berperan penting dalam penggumpalan serta pembentukan gel saat pengolahan. Protein stroma adalah protein jaringan ikat yang terdapat di luar serabut daging ikan.

Protein ikan berfungsi sebagai penambah jumlah protein yang dikonsumsi, sekaligus sebagai pelengkap mutu protein dalam menu. Hal ini disebabkan protein ikan memiliki komposisi asam amino yang lengkap, serta mengandung asam amino penting, lisin dan metionin, yang lebih tinggi dibanding kandungan protein susu dan daging. Selain protein, ikan juga mengandung minyak ikan yang kaya asam lemak tak jenuh jamak atau polyunsaturated fatty acids (PUFA) yang bemanfaat bagi kesehatan dan membantu perkembangan otak. Asam lemak tak jenuh jamak yang banyak terdapat pada ikan adalah asam lemak omega-3, terutama eikosapentaenoat/EPA (C20:5, n-3) dan dokosaheksaenoat/DHA (C22:6, $\mathrm{n}-3$ ). Kandungan asam lemak omega-3 bervariasi bergantung pada jenis ikan. Namun, pada umumnya komposisi minyak ikan laut lebih kompleks dan mengandung PUFA relatif lebih tinggi dibandingkan dengan ikan air tawar. Beberapa contoh kandungan gizi ikan tersaji di Tabel 1. 
Tabel 1. Kandungan Gizi lkan ${ }^{*}$

\begin{tabular}{lccccc}
\hline \multirow{2}{*}{ Jenis Ikan } & \multirow{2}{*}{$\begin{array}{c}\text { BDD } \\
\text { 100\% }\end{array}$} & \multicolumn{3}{c}{ Kandungan Zat Gizi per $\left.100 \mathrm{~g} \mathrm{BDD}{ }^{* *}\right)$} \\
\cline { 3 - 6 } & $\begin{array}{c}\text { Energi } \\
(\text { kkal) }\end{array}$ & $\begin{array}{c}\text { Protein } \\
(\mathrm{g})\end{array}$ & $\begin{array}{c}\text { Lemak } \\
(\mathrm{g})\end{array}$ & $\begin{array}{c}\text { Karbohidrat } \\
(\mathrm{g})\end{array}$ \\
\hline lkan Mas & 80 & 86 & 16,0 & 2,0 & 0,0 \\
Tawes & 80 & 198 & 19,0 & 13,0 & 0,0 \\
Bandeng & 80 & 129 & 20,0 & 4,8 & 0,0 \\
Kakap & 80 & 92 & 20,0 & 0,7 & 0,0 \\
Bawal & 80 & 96 & 19,0 & 1,7 & 0,0 \\
Hiu & 49 & 89 & 20,1 & 0,3 & 0,0 \\
Kembung & 80 & 103 & 22,0 & 1,0 & 0,0 \\
Teri & 100 & 77 & 16,0 & 1,0 & 0,0 \\
Rebon & 100 & 81 & 16,2 & 1,2 & 0,7 \\
Udang & 68 & 91 & 21,0 & 0,2 & 0,1 \\
Kepiting & 45 & 151 & 13,8 & 3,8 & 4,1 \\
Kerang & 20 & 59 & 8,0 & 1,1 & 3,6 \\
\hline
\end{tabular}

${ }^{*}$ ) Irianto \& Susilo, 2007;

$\left.{ }^{\star *}\right)$ BDD = Bobot Dapat Dimakan

Konsumsi ikan atau produk olahan berbasis ikan merupakan salah satu upaya untuk meningkatkan pemenuhan gizi masyarakat. Pemerintah melalui Kementerian Kelautan dan Perikanan (KKP) telah berkomitmen untuk meningkatkan konsumsi ikan pada masyarakat melalui kampanye Gemar Makan Ikan sebagai sumber protein hewani. Tujuan kampanye tersebut adalah untuk terus menciptakan sumberdaya manusia yang berkualitas dan handal sebagai pelaksana pembangunan.

\subsection{Teknologi Pengolahan Ikan}

Pengolahan ikan, selain untuk pengawetan, utamanya ditujukan untuk peningkatan penerimaan konsumen melalui rasa, aroma, dan penampakan produk. Lebih dari itu, teknologi pengolahan ikan, selain meningkatkan nilai tambah komoditas perikanan, juga memberikan pilihan berbagai produk untuk dikonsumsi masyarakat. Produk-produk hasil pengolahan ikan sangat digemari oleh masyarakat secara luas, baik anak-anak maupun orang dewasa. Umumnya produk tersebut dikonsumsi sebagai lauk utama, makanan ringan, atau snack. 
Pengolahan ikan dengan prinsip zero waste (Gambar 1) merupakan pengolahan ikan yang menggunakan semua bagian tubuh ikan, yaitu daging, kepala, tulang, sirip, kulit, air cucian, bahkan jeroan ikan untuk diolah menjadi berbagai produk olahan (Trilaksani \& Riyanto, 2008).

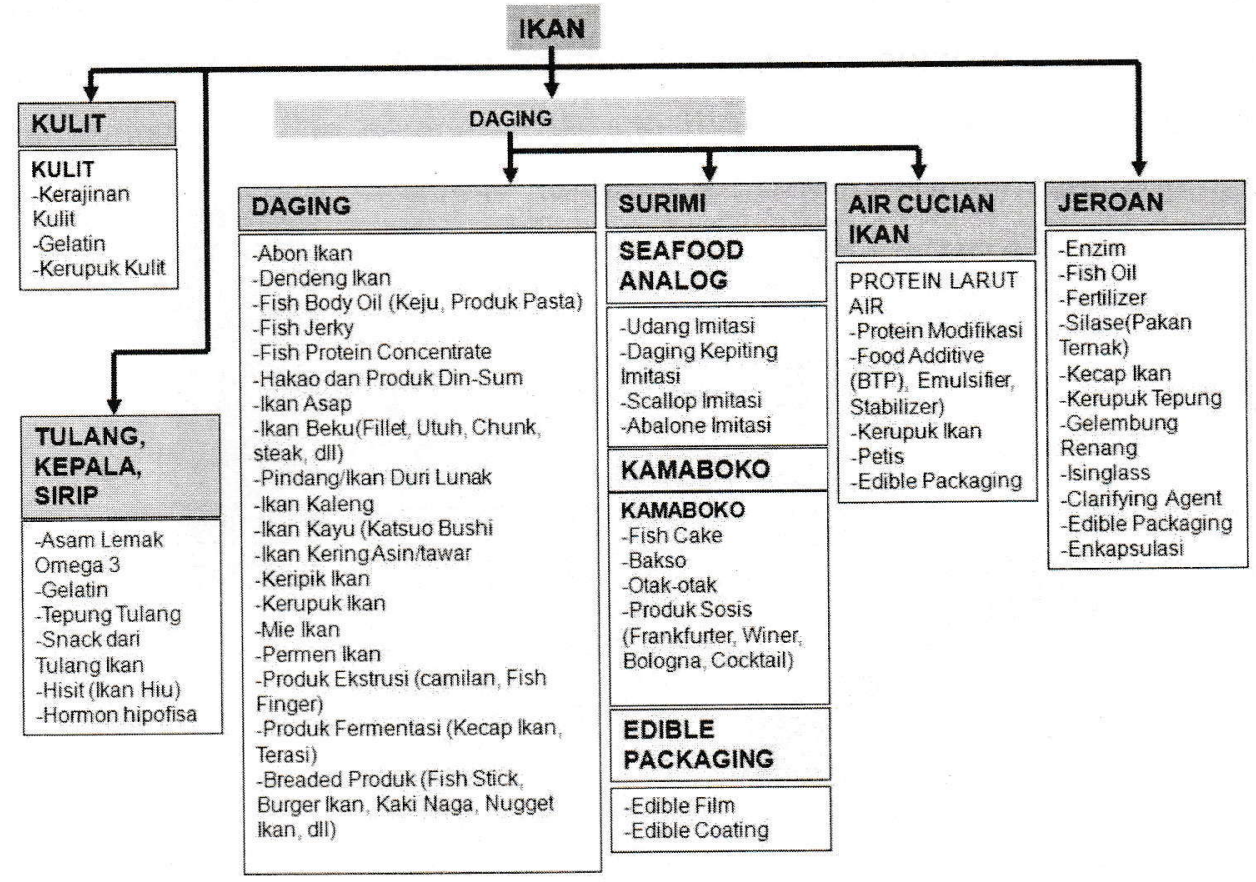

Gambar 1. Pengolahan ikan dengam prinsip zero waste (Trilaksani \& Riyanto, 2008)

Diversifikasi atau penganekaragaman produk olahan ikan adalah upaya untuk meningkatkan konsumsi masyarakat melalui penyediaan variasi pilihan produk olahan ikan. Diversifikasi bertujuan untuk memenuhi selera konsumen yang beragam dan terus berkembang sejalan dengan perubahan kebiasaan makan (food habbit). Diversifikasi produk olahan diharapkan mampu meningkatkan daya serap pasar serta sekaligus peningkatan kreativitas, para pengolah/produsen hasil perikanan untuk mengembangan produknya. 
Diversifikasi terdiri dari dua macam, yaitu diversifikasi horisontal dan diversifikasi vertikal. Diversifikasi horisontal adalah pengolahan berbagai jenis ikan menjadi produk olahan tertentu. Diversifikasi vertikal adalah pengolahan satu jenis ikan tertentu menjadi berbagai produk olahan ikan. Hal ini dapat dilakukan pada saat musim panen ikan yang berlimpah, atau pemanfaatan jenis ikan yang berdaging tebal (tenggiri, gabus, patin). Contoh diversifikasi vertikal dari ikan patin tersaji pada Gambar 2.

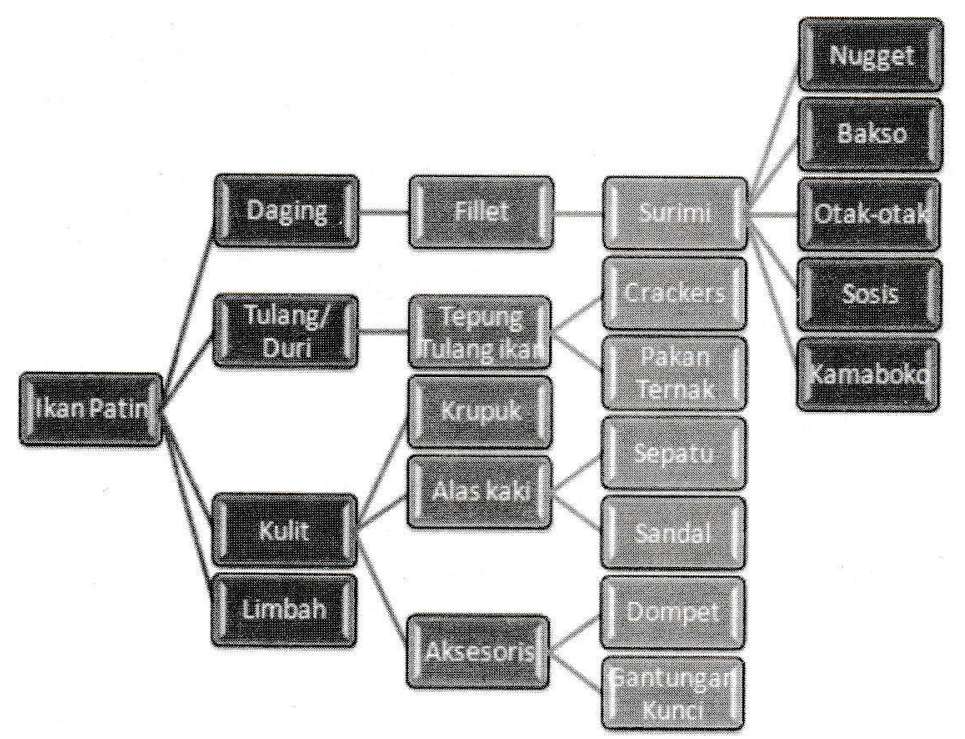

Gambar 2. Contoh diversifikasi vertikal ikan patin (Hidayat, et.al., 2011)

Beberapa jenis produk pengolahan hasil perikanan yang sudah dikenal dan banyak dikembangkan oleh masyarakat adalah bakso ikan, nugget ikan, abon ikan, kerupuk ikan, makanan tradisonal empek-empek, dan otak-otak. Salah satu bentuk dari aneka produk olahan hasil perikanan adalah sosis ikan. Pengolahan ikan menjadi produk sosis sangat potensial untuk dikembangkan mengingat permintaan pasar akan produk sosis cukup tinggi. Alternatif usaha perekonomian baru, yaitu produksi sosis ikan dapat diciptakan melalui pelatihan pengetahuan praktis pembuatan sosis ikan dan sosis ikan ekonomis. 


\subsection{Sosis Ikan}

Sosis merupakan produk daging giling yang bersifat kenyal dan berbentuk silinder dengan pembungkus khusus (casing). Kata "sosis" berasal dari Bahasa Latin, salsus, yang berarti "digarami" (Kramlich, 1971). Hal ini berkaitan dengan proses pembuatan sosis dengan daging sebagai bahan utama sosis yang diawetkan melalui penggaraman. Berdasarkan SNI 01-3820-1995, sosis daging adalah produk makanan yang diperoleh dari campuran daging halus (mengandung daging tidak kurang dari $75 \%$ ) dengan tepung atau pati dengan atau tanpa penambahan bumbu dan bahan tambahan makanan lain yang diizinkan dan dimasukkan ke dalam selubung sosis.

Secara umum sosis diartikan sebagai makanan yang dibuat dari daging lumat yang diberi bumbu atau rempah-rempah kemudian dimasukkan ke pembungkus berbentuk bulat panjang yang berupa usus hewan atau pembungkus sintetis (plastik). Sosis dapat dibuat dalam keadaan mentah, dimasak, atau pengasapan. Sosis yang banyak beredar di pasar saat ini adalah sosis sapi dan sosis ayam. Pemanfaatan ikan sebagai bahan baku pembuatan sosis masih belum dikembangkan oleh masyarakat.

Sosis ikan merupakan produk olahan daging ikan yang dibuat dengan cara menggiling dan menghaluskan filet ikan serta diberikan bumbu, kemudian dibentuk seperti silinder menggunakan casing sosis. Bahan utama yang digunakan adalah daging ikan segar yang berkualitas baik. Protein pada ikan segar bermutu baik karena mengandung protein yang larut dalam air (water soluble protein) dan protein yang larut dalam garam (salt soluble protein) yang berfungsi sebagai emulsifier dalam pembuatan adonan sosis ikan. Jenis ikan yang umum digunakan adalah ikan tengiri. Namun, pada dasarnya hampir semua jenis ikan dapat dimanfaatkan untuk membuat sosis bila dicampur dengan sejumlah lemak. 


\section{BAB II \\ BAHAN BAKU DAN ALAT PRODUKSI}

Bahan-bahan yang digunakan dalam pembuatan sosis ikan terdiri atas bahan utama dan bahan pendukung. Sebagai bahan utama adalah adalah daging ikan yang berkualitas baik. Sebagai bahan pendukung adalah lemak, garam, es, fosfat, bumbu-bumbu, bahan pengikat (binder), dan bahan pengisi (filler).

\subsection{Bahan Utama}

Bahan utama pembuatan sosis ikan adalah daging ikan yang segar. Ciri-ciri ikan segar dapat diketahui dari penampilan fisik seperti mata, daging, insang, sisik, kulit, bau, dan lendir. Ikan segar akan tampak mengkilap, memiliki mata cembung yang bening dengan pupil hitam dan tidak berdarah, daging kenyal ketika ditekan terutama di bagian perut, insang berwarna merah cerah, sisik masih menancap kuat, bagi ikan yang tidak bersisik maka kulitnya tidak mudah robek, memiliki bau amis khas ikan, serta mengandung sedikit lendir yang bening dan encer di permukaan tubuh.

Sebaliknya, ikan yang sudah tidak segar dan mulai busuk memiliki mata yang keruh dan tenggelam, daging yang lunak sehingga bila ditekan dengan jari akan tampak bekas lekukan, insang berwarna coklat suram atau abu-abu berhimpitan, sisik mudah lepas, untuk ikan yang tidak bersisik maka kulitnya mudah robek, lendir lebih keruh, dan bau asam sudah mulai banyak di permukaan tubuh ikan.

Kesegaran ikan sering dimanipulasi oleh pedagang ikan agar ikan tetap kelihatan segar dan tidak mudah rusak. Salah satu bahan pengawet berbahaya yang sering dipakai untuk menjaga kesegaran ikan adalah formalin. Zat formalin bila terserap tubuh akan menyebabkan mual, muntah, bahkan dapat berdampak serius pada kesehatan organ tubuh. Salah satu uji alami untuk mengetahui apakah ikan mengandung zat 


\section{SOSIS IKAN}

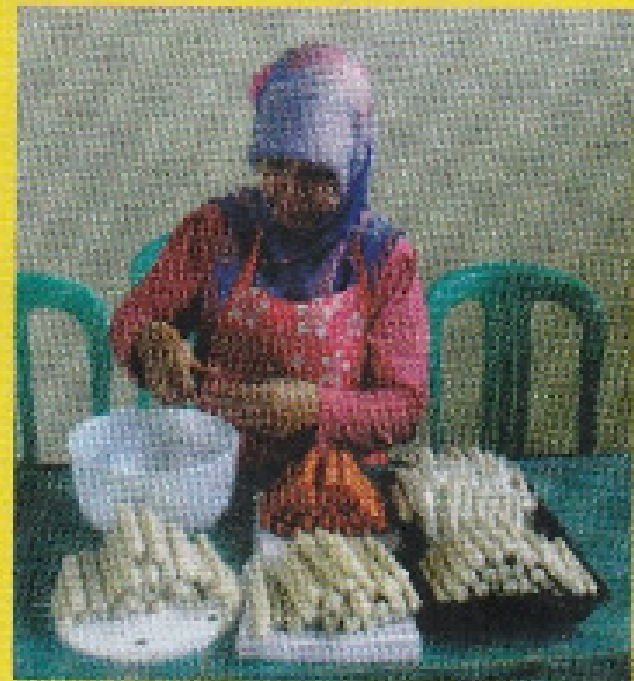

Ari Asnani, lahir di Jakarta 22 Maret 1969. Memperoleh gelar Sarjana Kimia dari Universitas Indonesia pada tahun 1993; Gelar Master of Science in Biochemistry diperolehnya dari UPLB Philippina tahun 1998; dan Gelar Ph.D dalam bidang Chemistry \& Biochemistry dari University of Guelph, Canada tahun 2007. Ari Asnani bekerja sebagai PNS yaitu sebagai dosen Kimia/ Biokimia sejak 1995. Saat ini Ari Asnani berafiliasi pada Jurusan Kimia, Fakultas MIPA, Universitas Jenderal Soedirman, Purwokerto. Pengalaman pembuatan sosis diperoleh berdasarkan pelatihan wirausaha sosis dan sosis ekonomis awal tahun 2014. Pengetahuan tersebut selanjutnya diaplikasikan dalam kegiatan IbM Wanita Ternak Ikan tahun 2014 dengan mitra wanita ternak ikan di Desa Luwung, Kecamatan Rakit, Kabupaten Banjarnegara. 